DOI: 10.1515/auseur-2017-0001

\title{
Why Multilingualism and Multilingual Communication Jeopardize a Common Social Policy for Europe ${ }^{1}$
}

\author{
László MARÁCZ \\ Institute for European Studies, University of Amsterdam \\ L.K.Maracz@uva.nl
}

\begin{abstract}
This paper studies the consequences of European multilingualism and multilingual communication for a common social policy in the Europe Union. In the past fifty years, the main focus of the Europeanization project has been on financial-economic developments and less on a common social policy. Even today, there is no common framework for social protection in the European Union. Common minimum income or wages for European citizens are lacking. In this paper, it will be argued that the lack of social protection has to do with Europe's linguistic diversity. Language is seen as a building block of national communities and their political cultures. The European integration project can only continue if different European political cultures are shared. However, due to the fact that a neutral lingua franca is lacking, this has been unsuccessful so far. The interaction of social groups that have a different language repertoire with the structures of multilevel governance are responsible for the fact that some of these social groups, including the 'Eurostars', and national cosmopolitans benefit from social protection, whereas other groups lacking relevant language skills, such as anti-establishment forces, commoners, and migrants, are excluded from the European power domains. These power configurations can be fruitfully studied in the floral figuration model. Consequently, due to these patterns of inclusion and exclusion, true solidarity among European citizens is not within reach. These claims will be illustrated by a case study on the Netherlands, a country that has been pursuing neoliberal policies counterbalancing Eurozone and economic crises and is trying to assimilate migrants and other newcomers. Apart from assimilatory policies targeting migrants, language games used by competing forces are playing an important role in the discourse in order to set up power structures.
\end{abstract}

Keywords: multilingualism, multilevel governance, Social Europe, floral figuration model, migrants, language games

1 The author is indebted to Jean-Claude Barbier for inspiring discussions on Social Europe. The research leading to these results has received funding from the European Union's Seventh Framework Programme (FP7/2007-2013) under Grant Agreement No 613344. 


\section{Introduction}

Commentators recognize that there is a close relation between politics, language, and solidarity at the level of national political cultures. According to Bo Rothstein (1998), although not being completely convinced of the role political cultures play concerning solidarity, social protection is conditioned by the perception of reciprocity. Reciprocity is, however, best guaranteed in a system of bounding and bonding, as outlined in Ferrera (2005). According to Maurizio Ferrera, social protection has always been dependent on two social mechanisms: first, the bounding of a territory, nation-state borders and, second, bonding, the creation of a bond of solidarity or sharing within the boundaries of the national community, which may temporarily include immigrants and relies on factors such as territory, nationality, residence, language, citizenship, and a sense of belonging to community. Note that among the factors inducing solidarity Ferrera refers to language as well. One of the key points of the relation between social protection and bounding/bonding lies in individual and collective willingness to share resources within a given political community. Although this position considers the relation between politics and language to be relevant for solidarity at the national level, this relation is seriously underestimated and neglected in research in the context of Europeanization. In a recent work on 'Social Policy in the European Union' published in the prestigious 'The European Union Series' by Karen Anderson (Anderson 2015), the term 'language' does not even appear.

Even Philippe Van Parijs, the advocate of turning international English into a global lingua franca in order to solve the problem of linguistic diversity and multilingual communication in Europe and the world, admits that a common language is a prerequisite for forming a demos, i.e. a nation-state in the sense of Ferrera, and that this demos is an important precondition for economic solidarity at a local level (Van Parijs 2011: 195). Hence, local solidarity is covered in the framework of Van Parijs, but solidarity on a European level is left in limbo. However, solidarity even within the context of the nation-state including a demos based on a common language remains a difficult matter, as Jeene et al. point out (Jeene et al. 2014). Dutch deservingness opinions fluctuate continuously depending on economic and political factors such as GDP, unemployment rate, and the national political climate. However, note that notions as 'demos', 'nationstate', 'national community', and so on are tied to the notion of 'national political culture', which is the relevant notion for analysis concerning social Europe, as it is convincingly argued in Barbier (2013).

According to Barbier (2013: 105), the concept of national political culture is inscribed in a given political community as a system of meanings embedded in history through collective practices, which are more or less formally institutionalized and support common representations of what is valued. This 
means that the pairing of language and politics is rooted in a network of common meanings conditioning political activity that generate their own discourses and cognitive frames. As a consequence, there is an individual and collective willingness to share resources within a given political community. European integration, including a common policy for Social Europe, would mean the sharing of political cultures for which a common multilingual political idiom will be required. However, if a common administrative language is a building block for solidarity, it is hard to imagine how a social policy at the European level could be realized when a common language or communication patterns including the European citizen are absent. For now, this is the present state of affairs since linguistic diversity is considered a cornerstone of European identity. This has led Wang and Steiner (2015) to reject the concept of linguistic diversity altogether, favouring homogeneous language communities. These authors argue that there is a relationship between linguistic fragmentation and social capital where the latter is characterized by trust, common norms, and networks. Countries with higher social capital tend to be richer. According to them, the number of languages in a country is significantly negatively correlated with social capital. This claim is not absolute, however. There can be more different languages spoken in a country, but important is how many citizens speak the same first language. The higher the number of citizens that speak the same first language, the more linguistic homogeneity there is, the better it is for social capital. Wang and Steiner point out that there are countries with high rates of social capital that are not linguistically homogeneous, such as Belgium and Canada. This can be explained by the fact that on the sub-state level, Flemish and Québécois national identity formation, including an independent language, are intertwining with social policy. However, introducing homogeneous linguistic communities at the European level causes patterns of exclusion, widening the gap between the European elites and the commoners, actually undermining Social Europe, as I will demonstrate below. From these introductory remarks, it is clear that language and communication are relevant for the design of a European social policy and that there is no a priori reason to avoid the role of languages and multilingual communication in research questions on this topic. It is precisely the neglect of the European multilingual structure that has caused the delay in the development of a social policy for Europe in the past fifty years, not guaranteeing fundamental files of social protection such as the minimum income or minimum wages for all European citizens.

Apart from Europe's multilingual identity, there is another, structural factor that is relevant for an analysis of the relation between European multilingualism and a social policy for Europe, i.e. the concept of multilevel governance within the European Union. Multilevel governance is an administrative system in which power is distributed and shared horizontally and vertically among many different levels of government, from the supranational to the local, with considerable 
interaction among the parts (see McCormick 2015: 32). With reference to the Union, the different levels are normally described as a tripartite system consisting of the 'macro'-level, i.e. the supranational EU-level, a 'meso'-level, i.e. the level of the Member States, and a 'micro'-level, i.e. the local level of government and policymaking (Hooghe-Marks 2001). This paper will investigate the relation between languages, multilingual communication, and social policy in Europe; more precisely, it offers an analysis of the present state of affairs, which is the result of the interplay of Europe's system of multilevel governance and its multilingual identity.

The question is how multilingualism and multilingual communication in Europe fit into the system of multilevel governance? For this purpose, I will adopt the floral figuration model for languages that has been proposed in De Swaan (1988) (see Figure 1). This model depicts the language competence of social groups and their hierarchical orderings in terms of power (Bourdieu 1991). Although De Swaan introduced the floral figuration model to track down the socio-political implications of linguistic relations at the national level, it is my conviction that his model can be used as a fruitful analytical frame for European Union purposes as well. The floral figuration model also gives insight into the position of international English, as I will discuss in this paper. International English is functioning more and more as a bridging language, a lingua franca in the European institutions in Brussels.

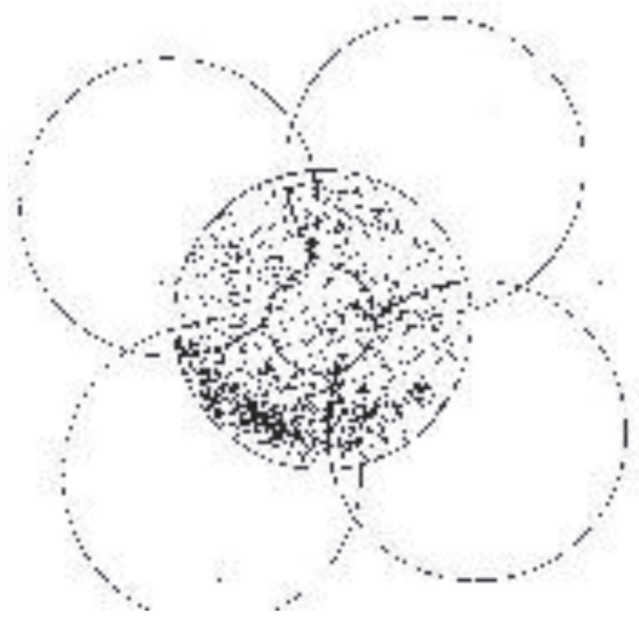

Figure 1. The floral figuration for linguistic actors in the European Union

This model will be empirically also tested in a case study on multilingualism and multilingual communication in the Netherlands. The Dutch government responded to the Eurozone crisis by introducing a neoliberal welfare policy and an assimilatory policy towards migrants. These policies had repercussions in 
the field of multiculturalism and multilingual communication, as I will discuss below. These repercussions unambiguously involve patterns of exclusion affecting linguistic actors. Hence, these patterns seriously hamper the design of a social policy for Europe that should be based on patterns of inclusion rather than exclusion. Hence the conclusion that languages and multilingual communication will be relevant for the realization of Social Europe. Let us briefly introduce the floral figuration for linguistic actors in the European Union.

This figure depicts the language situation in the European Union. In the outer circles, the European masses, the commoners in Europe's Member States are located. The commoners speak a national or regional language as their mother tongue; they have received some sort of basic (elementary and secondary) education in their mother tongue and might speak a European language of wider communication such as English, Spanish, French, or German. If they do speak a language of wider communication, it is not the standardized variety of these languages. Rather it will be an 'anything goes' variety. The shaded area represents speakers who belong to the European multilingual elites and who have a much better control of their mother tongue and the European languages of wider communication than the commoners. Fligstein refers to them as '...the educated, owners of business, managers, and professionals, and the young' (Fligstein 2008: 156). These groups form in fact a 'class' and participate in transnational networks within Europe. Those in the core star are the European cosmopolitan elites, the Eurostars, as Adrian Favell calls them (Favell 2008: 144, 145). They use English as the European communication language. Merje Kuus, who interviewed a number of European diplomats in the European External Action Service, describes this operating language as 'a technical language of eurospeak' (Kuus 2014: 56). Note further that in the floral figuration model local speech communities are hardly intersecting with each other, but all of them are linked to multilingual local elites through the mediation of one central or national language. These local, regional, or national elites - I will refer to them as national cosmopolitans - are acting as interfaces between the commoners, who have basically monolingual language and communication skills, and the 'multilingual' Eurostars. 'Multilingual' means first and foremost 'this technical language of eurospeak', which is based on English and is functioning as a lingua franca. This adapted version of English in the Brussels institutions is sometimes also referred to as 'Euro-English'. Hence, the shaded area is communicating via Euro-English at the expense of the other official European languages, including standard British English. The floral figuration model depicted in Figure 1 is not sophisticated enough to describe all the positions of relevant linguistic actors in Europe. My analysis in terms of this model is to be considered as a first approximation of the various interests that determine the sociological aspects of European linguistic diversity. I will leave the detailed elaboration of it, a flower with much more leaves, as a task for further research. 
Four groups will be relevant in the discussion of the Dutch case study below, namely the national cosmopolitans, anti-establishment forces, commoners, and migrants. The national cosmopolitans determine the normative variety of the Dutch standard language, which allows them to include their own clientele and to exclude commoners and migrants not controlling the normative variety of Dutch. The former are included into the shaded areas; the latter are excluded from these. The anti-establishment forces who communicate in their vernacular with the commoners have quite often a poor command of English, whatever its variety. Hence, I exclude them from the shaded areas in Figure 1, although from a political point of view the Eurosceptics and Eurorejects are represented in the Brussels political arenas but not in the 'intermediate sphere' in the sense of Van Middelaar (2013), who has argued that there is an added 'European' value to the space of European cooperation. The Eurosceptics and Eurorejects are the 'populists' referred to by the European elites. The anti-establishment forces use and misuse the power of language when communicating with the local commoners in their vernacular and using a direct style and language games on sensitive issues such as the inclusion of internally mobile European citizens or immigrants from outside Europe and other newcomers; or when communicating on the Eurozone crisis that might endanger the national welfare state. The anti-establishment parties also communicate with the European elites, i.e. both with the Eurostars and the national cosmopolitans, but this communication is negative and exclusionist, directed at undermining European integration. The anti-establishment forces compete with the national cosmopolitans by using direct communication lines reaching out to the commoners in their common vernaculars. This pattern forces the national cosmopolitans to adapt to the language and rhetoric used by the Eurosceptics and to speak with a 'forked tongue' in order not to lose their electorate to these forces, as the Dutch case study will demonstrate. Migrants are in principle located in the unshaded, outer circles. If they adapt to the host situation and learn the host language, they will be able to communicate via the national cosmopolitans with Brussels. However, if migrants have a deficient control of the host language or its normative standard, they might face isolation, lacking a channel to communicate with Brussels, or discrimination on the labour market of the host country. Note that they have the possibility to open their own transnational network with peers in the other outer circles, an option commoners in the Member States hardly have. In sum, this set of exclusionist patterns that are depicted by the floral figuration model for language and communication cannot form a solid basis for Social Europe. 


\section{Languages and Multilingual Communication in Europe}

From its founding treaty in 1958, Europe has stipulated that all the languages of the Member States are official languages. Language regulation 1/1958 turned four languages - official and regional languages in France, Germany, Italy, and the Benelux countries - into official European languages (Labrie 1994). These languages included French (France, Belgium, Luxemburg, and Italy), German (Germany, Belgium, Luxemburg, and Italy), Italian (Italy), and Dutch (the Netherlands, and Belgium). These four languages enjoyed an equal status in the institutions of the European Common Market, implying that they were to be used as institutional and working languages. With every new round of expansion, new Member States had the right to propose new official languages. The language regulation remained operative and all official languages of new Member States were recognized as official European languages. At present, the EU recognizes 24 official languages. Linguistic diversity in Brussels is hard to manage, however. Hence, the distinction between 'official' versus 'working' language has become relevant, and this is practically used as a solution for the language issue in the Brussels institutions. The difference between official and working languages is defined in Article 6 of the language regulation: the institutions are allowed to freely choose their own language regime. The European Commission acknowledges three working languages, namely English, which is used the most, French, and German. The latter is used substantially less frequently than the other two (Marácz-Rosello 2012). Another example of Article 6 is the fact that of the 15 Directorate Generals (DGs) only three use the 24 official languages on their website, including Employment, Social Affairs and Inclusion (EMPL), Enterprise and Industry (ENTR), and Justice (Just) (Gazzola 2014). All other DGs use a reduced or a monolingual regime consisting of English only.

There are voices to abolish Language Regulation 1/1958 altogether due to the fact that an equal treatment of official and working languages is not possible. The main argument is that the democratic language regime of the EU will hamper an efficient functioning of its institutions. Moreover, the reduction of the number of official languages is underpinned by the fact that international English functions practically as a lingua franca in Brussels and the European educational recommendations for languages favour the learning of English (Haselhuber 2012). Hence, monolingualism, i.e. the use of international English, is getting more and more the practice in Brussels. But not only the introduction of a variety of international English as a European lingua franca, let us say Euro-English, will hamper the equality of languages in Brussels. It will also render almost impossible the participation of non-speakers of English in the Europeanization project. Let us discuss this claim in more detail.

It is clear that English is on the rise as a global lingua franca. Phillipson (2006, 2009), De Swaan (2001), Grin (2014), and Ricento (2015) convincingly argue that 
the expansion of English on a global scale is driven by the hegemonic political and economic positions established first by the British Empire and later on in the twentieth century by the United States. However, for a number of reasons, the situation of global English is not unproblematic. Firstly, the conclusion is justified that English is associated with linguistic hegemony and domination at the expense of other languages. Secondly, English cannot function as a real lingua franca that is a neutral mediator language respecting the linguistic background of all speakers involved in the communicative event due to the fact that it is spoken by native and non-native speakers. Thirdly, there are different versions of English in use, such as British English, American English, and so on, which makes it for the foreign speakers of English difficult to know what the precise norms of English are, although there exists a regularly accepted normative variety of English, standard British English, spread by important language mediators, such as BBC radio and television, and is taught to foreign speakers of English in formal education. So, the variety of global English functioning as a bridge language among non-natives should in fact be English-as-a-foreign language. However, it has been observed that this normative variety of English is not spoken across the globe but rather a basic version of English mixing, intermingling with and sampling local languages as an outcome of language use and communication (Edwards 2012: 34-38, Hülmbauer et al. 2008).

Let us remember that Figure 1 depicts linguistic diversity in terms of a demarcation between European elites and commoners. The European elites, i.e. the Eurostars and the national cosmopolitans, although positioned in different geographical spaces, i.e. the Brussels centre and the Member States, are positioned in a common virtual space. They form a connected transnational class and speak the same sort of fluid language for instrumental communicative purposes only, i.e. a European variety of international English, i.e. Euro-English. Euro-English is developing its own characteristics, such as misused English words and expressions (European Court of Auditors 2013), and has adopted artificial expressions, e.g. from the financial world, such as 'collateralized debt obligations', 'asset-backed securities', and 'credit default swaps' (Maier 2014: 210). This is 'de-contextualized English' pinned down in Barbier (2014), or 'the technical language of eurospeak' Kuus (2014) is referring to. It is hard to imagine that this variety of English will be able to mediate between the different political cultures in Europe that are rooted in language, as Ferrera (2005) and Barbier (2013, 2014) argue for. However, whatever its status or quality, according to the last dataset of Eurobarometer (see Eurobarometer 386), roughly 50 percent of the EU citizens do not have any knowledge of English at all. So, a restricted linguistic regime with English or consisting of English-only would privilege the higher educated, the better-off in Europe, seriously undermining Social Europe (Gazzola 2014). Let us now turn to a case study of the Netherlands. 


\section{Dutch Responses to the Eurozone Crisis}

The Netherlands has been one of the six founding countries of the common Europe and a strong proponent of the establishment of the single European market and the four cross-border freedoms in the EU (Van Middelaar 2013). Dutch mainstream political parties have been supporting the establishment of the single market in the Maastricht Treaty in order to profit optimally from a financial-economic policy that is based first and foremost on ever-increasing markets, trade, and export (Van Meurs et al. 2013). This massive mainstream support for transnational concepts, such as Europeanization and globalization, ties in with the classical Dutch state policy of 'mercantilism' and matches very well with the ideology of 'neoliberalism'.

Barbier (2013: 71) observes that the Netherlands does not fit into the classical typology of welfare states, elaborated in Esping-Andersen (1990), including the three types of liberal, conservative-corporatist, and social-democrat. The Netherlands is traditionally of the liberal type characterized by its genuine 'mercantile' spirit, but it has in due course adopted elements of the other two models as well. This has yielded a hybrid type of welfare state. Recently, under the pressure of the global neoliberal market forces, the liberal profile has gained the upper hand, though. A liberal policy is considered to be a recipe to solve the Eurozone crisis. In a neoliberal state, the state withdraws from the socioeconomic domains, citizens are expected to become directly responsible for their own social welfare, and the state has no other obligation than facilitating its citizens to obtain more social welfare strictly limited to its territory. Due to this neoliberal policy, the Dutch lower and middle classes fear that they cannot rely any longer on the state for their social welfare and the traditional social protection. Although the neoliberal ideology has dominated thinking about the preservation of the social welfare state in the Netherlands, different responses to the challenges of Europeanization, globalization, and the ensuing Eurozone crisis have also appeared in recent times. Anti-establishment parties have successfully mobilized the fears among the Dutch electorate, especially since the outbreak of the Eurozone crisis in 2009, threatening that the Netherlands would leave the Eurozone in order to protect its own national welfare system. Furthermore, the absence of positive integration in the domain of migration policy has given anti-establishment parties an extensive electoral agenda (Scharpf 2010). In the traditional neighbourhoods of larger Dutch cities, the local commoners had to pay the price of worsening social services due to neoliberal state policy. In these neighbourhoods, social relations were already tense because of a massive influx of migrants, especially those with a different, non-Western European cultural background, not being absorbed and assimilated successfully. 
In 2001-2002, on the waves of these social tensions, Dutch anti-establishment politician Pim Fortuyn succeeded in mobilizing large groups of commoners to strengthen Dutch national identity, to put a more restrictive migration policy and an anti-European stance on the political agenda. After Fortuyn's assassination in May 2002, his heritage was taken over by Geert Wilders, a liberal politician and former member of the VVD (People's Party for Freedom and Democracy), who established the PVV (Party for Freedom). The PVV has been successfully challenging the mainstream political parties with anti-establishment, strong anti-immigration, anti-Islamic, and Eurosceptic rhetoric. The party entered the Dutch Parliament in 2006 and doubled its mandates in the 2010 parliamentary elections. As an outcome of these elections, the party agreed to back a centre right-liberal minority government of liberals (VVD) and Christian democrats (CDA, the Call of Christian Democracy), resulting in the First Rutte cabinet. This cabinet had to step down, however, due to the fact that the PVV withdrew its support for new austerity measures. Since then, the relation between the PVV and the mainstream parties has cooled down because it has become clear that the PVV does not want to take any responsibility for electorally delicate measures. This has led to a clear division between the mainstream left-liberal parties and anti-establishment parties.

In fact, this political demarcation correlates with a societal demarcation, as has been observed in a recent study entitled 'Separate Worlds' (Boven et al. 2014). Boven et al., who conducted this research on behalf of the Netherlands Institute for Social Research (SCP) and the Scientific Council for Government Policy (WRR), have studied opposing socio-cultural values, including universalist versus particularistic opinion, global versus local orientation, integration versus demarcation, Europhile versus Eurosceptic stance, perspectives with conflicts versus perspectives without conflicts, reflexive versus direct communication style, trust in politics versus distrust in politics, social trust versus social distrust, and found that these values are correlating with higher and lower educated groups, respectively, in the Dutch society. Furthermore, they discovered that these values correlate with party preference, the former values being popular among the electorate of mainstream left-liberal parties, while the latter ones among the electorate of anti-establishment parties such as the PVV and its socialist counterpart Eurosceptic SP (Socialist Party).

With respect to the Dutch case, I will discuss two patterns of multilingual and communicative communication in the framework of the floral figuration model. The first pattern concentrates on the communication between the Brussels core and the Dutch commoners, which is mediated via the national cosmopolitans. I will demonstrate that it involves a pattern of exclusion. A second pattern of linguistic and communicative exclusion concerns the migrants in the Netherlands. 


\section{Forked-Tongue Speak}

A key role is played by the national cosmopolitans, who are acting as an interface between the Brussels Eurostars and their peer commoners. Dutch Prime Minister Mark Rutte, representative of the liberal VVD, is a typical mainstream Dutch politician who has been in office since 2010. Between 2010 and 2012, together with the Christian democratic CDA backed by Wilders' PVV, he headed a centreright minority government. Since 2012, Rutte has been in charge of a coalition government with the Dutch Labour Party PvdA. PM Rutte is an active player in the Brussels political arena, the intermediate sphere referred to above. Rutte and his liberal supporters, who can be classified as national cosmopolitans, are acting as interfaces between the Eurostars and the Dutch electorate, which has been growing more sympathetic to Euroscepticism over the years.

Rutte is generally viewed as a 'Janus-faced politician' and speaking with a 'forked tongue'. This means he is a Europhile in Brussels and a Eurosceptic in The Hague (De Bruijn 2012). His VVD party tries to sell this double position of the Dutch PM as a clever negotiation strategy: 'If you say in Brussels always yes, they will like you. If you say once in a while no, they take you serious[ly]. They take Mark serious[ly] in Europe' (De Bruijn 2012). The argument of Rutte's supporters is that a Eurosceptic attitude in Brussels is necessary to get a better negotiation position and to convince Dutch Eurosceptic voters that the South European countries will be financially supported in the end; but not at any price. The Dutch $\mathrm{PM}$, who is aware of his Janus-faced position, is playing tactical language games in media performances. Rutte attended the European summit of 22-24 November 2012, where the Union's long-term budget and the Greek financial crisis were discussed, as he stated with 'a loaded gun in his pocket', but he quickly added that he would not use it, however: 'If you put it on the table, you put the negotiations under such a pressure that they will have no result' (Rutte 2012).

Due to the interface-like position of national cosmopolitan politicians, they are necessarily Janus-faced politicians, who speak with a forked tongue. Being part of the intermediate sphere in Brussels and at the same time participating in their home political arena, they send out their messages to different audiences simultaneously and address their electorate in a reflexive communication style (Bovens et al. 2014). Rutte's sentences are long and the topics are complicated. When he refers to his model of Social Europe as a 'participation society', he in fact implies the participation of every citizen in 'a complex network society' (Rutte 2013). A complex network society is understood here in the sense of Castells (Castells 2013, 2014), who argues that network society, the social structure that characterizes society in the early twenty-first century is constructed around digital networks of communication (Castells 2013: 4). However, such concepts are rather difficult to grasp for common citizens. Eurosceptics have a more 
transparent position in the level playing field, which are the outer circles in the floral figuration model. Although they are present in the Brussels arena, they do not really participate in it, they are not part of the intermediate sphere where Brussels politics is made, and hence there is no need for 'doublespeak' (PoolGrofman 1984). Anti-establishment politicians can address the electorate in their own vernacular, in a language easier to process, and in a direct communication style. Wilders and his PVV express a clear anti-European stance, even though they are represented in the EP, when they warn the electorate for the Netherlands' becoming a 'province of the European super-state' (Dossier Wilders 2010: 26).

The mainstream Janus-faced parties, such as the liberal VVD, the Christian democratic CDA, and the social democratic PvdA, which support the European project, have a hard time struggling with Eurosceptic parties, such as the PVV or SP, when European topics in the Dutch arena are at stake. Jean-Claude Juncker, the President of the European Commission, accused the mainstream Dutch parties of not protecting the EU in the Dutch referendum on the European Constitution in 2005, when more than 60 percent of the Dutch electorate voted against it. According to him, the mainstream political parties imitate the 'populist' parties: 'In the end, the European Parliament will only have Eurosceptics. That would be a catastrophe' (Juncker 2014).

\section{Migrants Must Speak Dutch}

The Netherlands has been actively supporting mobility and other forms of migration as an outcome of the four European freedoms and the liberal state doctrine. With respect to the inclusion of migrants, two periods of policy-making in the Netherlands can be distinguished.

The first period started in 1983, when the official policy document on migration stated that migrants had the right to preserve their heritage languages and cultures. As an outcome of this policy, it was possible for migrant children to receive education in their home language in elementary schools paid for by the government. This educational policy gave contents to the concept of a multicultural society. However, in-depth studies on the language proficiency of migrants' children, who had participated in home language education in elementary school, radically changed the policy perspective. It turned out that especially Turkish and Moroccan youngsters in their last year of elementary education at the age of twelve faced serious deficient language skills in Dutch compared to their Dutch classmates (Crul-Doomernik 2003). Due to the delay in language development, migrant children had to qualify for lower types of secondary education, resulting in much worse positions on the labour market. The government led by the Christian democratic PM Balkenende concluded that 
this situation was caused by the fact that migrant children were also educated in their home language at elementary school and by the fact that they spoke with their parents, who also faced deficient language skills in Dutch, their heritage language at home. Hence, the second Balkenende cabinet decided to abolish the state-sponsored heritage language education of migrant children in elementary school in 2004. From then on, all educational efforts were concentrated on teaching migrants and their children Dutch at school and preferably also in the home context. The switch from a multicultural to an assimilatory language policy was motivated first and foremost on economic ground. It was argued that improving Dutch language proficiency among migrants and their children was needed for strengthening their position on the labour market (Koopmans 2015). However, this switch did not imply that migrants and their children were integrated successfully into the Dutch society. Not only migrants are facing assimilatory pressure in the European Union, including the Netherlands, but also internally mobile European citizens such as workers from Eastern Europe. Council Directive 77/486/EEC of 25 July 1977 on the education of the children of migrant workers (see Official Journal of the European Communities No L199/32, 6 August 1977) in their own mother tongue has hardly been facilitated in the member states of the Union.

The outer circle of the floral configuration model has become a space for 'othering' and exclusion of migrants. Anti-establishment politicians, such as Wilders, used the mobilizing power of language in the political messages targeted at 'his' commoners, who were affected by the Eurozone crisis mostly, and discriminated internally mobile European citizens, such as Poles, and immigrants from outside Europe, or other newcomers, especially Muslims, with language games. Consider some of these examples.

In the annual general political debate in the Dutch Parliament on 16 September 2009, Wilders proposed to tax the Muslim headscarf as an expression of his disgust for this symbol of Muslim faith among women. He expressed this by his newly coined Dutch word 'hoofddoekjestaks'. Note the typical use of the Dutch diminutive plural '-jes' suffix attached to 'hoofddoek'- 'headscarf' and the Dutch spelling, i.e. 'taks' for English 'tax', emphasizing the opportunistic nature of this form of taxes on purpose and not using the Dutch ordinary word 'belasting' for 'taxes'. His proposal was received with unbelief in the Dutch Parliament. At some point, it was considered as a joke in bad taste, but then it all got the humiliating exclusive contents by replacing 'hoofddoekjestaks' with 'kopvoddentaks', which means 'head rag tax', where the Dutch word 'kop' has a clear pejorative meaning compared to the normal Dutch word for "head", i.e. 'hoofd'. According to Wilders, the 'kopvoddentaks' actually implies that any Muslim woman who wants to wear a headscarf would have to apply for a licence, and pay one thousand euros for the privilege. Wilders claimed the money raised would be used to support women's 
emancipation programmes (Kuitenbrouwer 2010: 34-36). Another neologism with the intention of othering and exclusion of Muslim immigrants is Wilders' term 'haatbaard', i.e. 'hate-beard': 'Our streetscape starts to look in some places more like the one of Mecca and Teheran. Headscarves, hate-beards, burqas, men in weird long white dresses. Let us do something against this.' Wilders refers with the expression 'hate-beard' to Muslims who distribute hate speech and/or wear a beard (Kuitenbrouwer 2010: 96). With the newly coined term 'straatterroristen', i.e. 'street terrorists', Wilders is referring to street gangs of Dutch-Moroccan youngsters. However, instead of associating these gangs with acts of crimes, he associates them with ideologically motivated acts of violence such as the killing of Dutch film director Theo van Gogh by Dutch-Moroccan Muslim fundamentalist Mohammed Bouyeri (Dossier Wilders 2010: 198) and the 'Islamic intifada', i.e. the political-ideological struggle of the Palestinians in Israel (De Bruijn 2010: 26). In sum, Wilders' rhetoric language is used as a political tool (Pool-Grofman, 1984) to mobilize 'his' electorate, the Dutch commoners, and to exclude migrants.

However, not only Dutch anti-establishment forces use language to demarcate socio-political positions but also the national cosmopolitans, i.e. the mainstream political parties and their clientele who are representing the state power, use language for purposes of demarcation and exclusion as well. They use their power positions by controlling the normative variety of the official language of the Dutch state. This allows them to include their own clientele and exclude migrants and newcomers from the labour market. The study of Ghorashi and Van Tilburg (2006) among a hundred highly educated refugee women, especially from Iran and Afghanistan who have gained the highest possible language skills for foreigners in the Netherlands, demonstrates that these language skills seem to be the main obstacle to enter the labour market in the Netherlands. When applying for a job with a better organization or company, they received the response that 'our company stands for high quality and people with accents do not fit the image of the organization'. Ghorashi and Van Tilburg conclude that 'neither knowledge of the Dutch language nor obtaining a higher degree in the Netherlands is enough for integration in the Dutch labour force' (Ghorashi and Van Tilburg 2006: 62). Hence, the Dutch assimilatory policy may give entrance to the labour market, but discrimination is practised by controlling the normative variety of the Dutch language. Note that national cosmopolitan elites use in much more subtle manner the normative variety of Dutch for exclusionary practice than their anti-establishment counterparts. Contrary to the direct communication of othering used by anti-establishment forces, this represents a more hidden form of exclusion. 


\section{Conclusions and a Research Agenda}

So far, Europeanization has been a project that has served the interests of the European elites, i.e. of those that can make optimal use of the European freedoms, mobility, and markets. In the framework of the floral figuration model, I referred to the European elites as Eurostars and national cosmopolitans. However, the challenge is to keep Europe attractive not only for its elites but also for its commoners. Wallace et al. (2015) observe that social policy within the EU is still a matter of the Member States. Hence, the task is to develop a genuine Social Europe that offers solidarity for all of its citizens. Although the diverging interests between the European elites and commoners has been noticed in the literature, such as in Neil Fligstein's 'Euro-clash' (Fligstein 2008), it has gone unnoticed that the Euro-clash between social groups involves unbridgeable language conflicts as well. These language conflicts have been intensified due to the Eurozone crisis.

In this paper, I have argued that language issues are vital for the development of Social Europe. Although the importance of language and communication is recognized at the state level, this topic is quite often neglected when it comes to the European level. The interplay between multilevel and linguistic governance in Europe can best be analysed in terms of the floral figuration model in the sense of De Swaan (1988). The typology of social actors, their language skills, their communication channels and styles, and their positioning in this model demonstrate that in the present constellation transparent, efficient, and fair communication is impossible. The multilingual communication patterns are first and foremost groupspecific and exclusivist, as the case study of the Netherlands demonstrates. This country has recently opted for a neoliberal welfare system to address the Eurozone crisis; it has been unable to cope with recent mass immigration and, as a consequence, it has experienced a Euro-clash in which anti-establishment parties have become fixed political forces. The types of patterns of linguistic and communicative exclusion that turn up in the Dutch case will block any form of genuine solidarity or any relevant initiative for a common social policy in Europe. The introduction of an English-based lingua franca in Europe referred to as Euro-English will not be sufficient to solve the linguistic and communicative deficits. English as a code of functional communication is not equipped to bridge the subtle semantics and concepts inherent in the social and political cultures of Europe. A standardized variety of English, i.e. BBC English, is also unfit to function as a European bridge language due to native speaker involvement excluding non-natives from native norms. Hence, the absence of a neutral, transparent, and accessible lingua franca jeopardizes the development of Social Europe. Neither will the official language policy of the European Union in education, the so-called $1+2$ formula, i.e. the teaching of a mother tongue and two other European languages (Marácz \& Rosello 2012: 22), overcome linguistic and communicative exclusion due to the fact that 
this scheme will only be able to cover a subset of the 24 official languages of the Union. In case English will be one of the languages in the $1+2$ scheme, similar problems will arise, as just discussed in case English would be used as a bridge language. Hence, a way out of this language-use deadlock would be to elaborate on multilingual and transnational communication codes based on fairness. Here I agree with Jean-Claude Barbier (2013: 21) that these codes must include plural idioms that are bridged by multilingual and transnational communication strategies, such neutral lingua franca communication, including artificial languages like Esperanto, Ido, and so on, translation and interpretation, which is already used extensively in the Brussels institutions, and intercomprehension. The latter is a multilingual communication technique that interlocutors can rely on when all of them speak their own mother tongue in a communication event. This is especially effective when related languages, such as the ones of the Romance or Germanic language families, are being used. As a task for further research, I will elaborate on the refinement of the floral figuration model against the background of the typology of welfare states proposed by Esping-Andersen (see Esping-Andersen 1990). It is to be expected that much more patterns of linguistic and communicative exclusion will turn up in the process of fine-tuning.

\section{References}

ANDERSON, Karen M. 2015. Social Policy in the European Union. Palgrave, London.

BARBIER, Jean-Claude. 2013. The Road to Social Europe: A Contemporary Approach to Political Cultures and Diversity in Europe. Routledge, LondonNew York.

2014. The Myth of English Language Competence in Europe and Some of Its Consequences. Paper presented at the Symposium Economics, Linguistic, Justice and Language Policy. Humboldt-Universität zu Berlin, 2-3 March 2015. BOURDIEU, Pierre. 1991. Language and Symbolic Power. Polity Press, Cambridge. BOVENS, Mark et al. (eds). 2014. Gescheiden werelden? Een verkenning van sociaal-culturele tegenstellingen in Nederland. Den Haag, Sociaal en Cultureel Planbureau en Wetenschappelijke Raad voor het Regeringsbeleid.

CASTELLS, Manuel. 2013. Communication Power. Oxford University Press, Oxford.

2014. The Power of Identity. Second Edition with a New Preface. WileyBlackwell, Oxford.

CRUL, Maurice-DOOMERNIK, Jeroen. 2003. The Turkish and Moroccan Second Generation in the Netherlands: Divergent Trends between and Polarization within the Two Groups. In: International Migration Review 37(4): 1039-1064. 
DE BRUIJN, Hans. 2010. Geert Wilders in debat. Over de framing en reframing van een politieke boodschap. Boom Lemma Uitgevers, Den Haag.

DE SWAAN, Abram. 1988. Care of the State: Health Care, Education and Welfare in Europe and the USA in the Modern Era. Oxford University Press, New York. 2001. Words of the World: The Global System. Polity Press, Cambridge.

EDWARDS, John. 2012. Multilingualism. Understanding Linguistic Diversity. Continuum, London.

ESPING-ANDERSEN, Gosta. 1990. The Three Worlds of Welfare Capitalism. Polity Press, Cambridge.

FAVELL, Adrian. 2008. Eurostars and Eurocities: Free Movement and Mobility in an Integrating Europe. Blackwell Publishing, Oxford.

FERRERA, Maurizio. 2005. The Boundaries of Welfare, European Integration and the New Spatial Politics of Social Protection. Oxford University Press, Oxford.

FLIGSTEIN, Neil. 2008. Euro-Clash, the EU, European Identity and the Future of Europe. Oxford University Press, Oxford.

GAZZOLA, Michele. 2014. Multilingualism for Effective Communication. An Evaluation of the European Commission's de facto Language Policy. Paper presented at the conference Multidisciplinary Approaches in Language Policy and Planning, 4-6 September 2014, University of Calgary.

GHORASHI, Halleh-VAN TILBURG, Maria. 2006. When Is My Dutch Good Enough? Experiences of Refugee Women with Dutch Labour Organizations. In: JIMI/RIMI 7(1) Winter/hiver, 51-70.

GRIN, François. 2014. Fashionable Sociolinguistic Constructs: Some Implications for Politics and Policy. Paper presented at the RECODE Workshop The Politics of Multilingualism: Linguistic Governance, Globalisation and Europeanization, 19-20 June 2014, University of Geneva.

HASELHUBER, Jacob. 2012. Mehrsprachigkeit in der Europäischen Union: eine Analyse der EU-Sprachenpolitik, mit besonderem Fokus auf Deutschland. Peter Lang, Frankfurt am Main.

HOOGHE, Liesbet-MARKS, Gary. 2001. Multi-Level Governance and European Integration. Rowman and Littlefield, Oxford.

HÜLMBAUER, Cornelia-BÖHRINGER, Heike-SEIDLHOFER, Barbara. 2008. Introducing English as a Lingua Franca (ELF): Precursor and Partner in Intercultural Communication. In: Synergies Europe 3: 25-36.

JEENE, Marjolein-Van OORSCHOT, Wim-UUNK, Wilfre. 2014. The Dynamics of Welfare Opinions in Changing, Economic, Institutional and Political Contexts: an Empirical Analysis of Dutch Deservingness Opinions, 1975-2006. In: Social Indicators Research.

KUITENBROUWER, Ja. 2010. De woorden van Wilders en hoe ze werken. De Bezige Bij, Amsterdam. 
KOOPMANS, Ruu. 2015. Does Assimilation Work? Socio-Cultural Determinants of Labor Market Participation of European Muslims. Unpublished Manuscript, Humboldt University Berlin.

KUUS, Merje. 2014. Geopolitics and Expertise. Knowledge and Authority in European Diplomacy. Wiley Blackwell, Oxford.

LABRIE, Norman. 1994. La construction linguistique de la Communauté Européenne. Champion, Paris.

MAIER, Michae. 2014. Die Plünderung der Welt, Wie die Finanz-Eliten unsere Enteignung planen. Finanzbuch Verlag, Munich.

MARÁCZ, László-ROSELLO, Mireille (eds). 2012. Multilingual Europe, Multilingual Europeans. Rodopi, Amsterdam-New York.

McCORMICK, John. 2015. European Union Politics. Palgrave MacMillan, Basingstoke.

PHILLIPSON, Robert. 2006. English-Only Europe? Challenging Language Policy. Routledge, London.

2009. Linguistic Imperialism Continued. Routledge, New York.

POOL, Jonathan-GROFMAN, Bernard. 1984. Language as Political Control: Newspeak Revisited. Paper Prepared for the 1984 Annual Meeting of the American Political Science Association. Washington, D.C., 30 August-2 September 1984.

RICENTO, Thomas (ed.). 2015. Language Policy and Political Economy: English in a Global Context. Oxford University Press, Oxford.

ROTHSTEIN, Bo. 1998. Just Institutions Matter: the Moral and Political Logic of the Universal Welfare State. Cambridge University Press, Cambridge.

SCHARPF, Fritz W. 2010. The Asymmetry of European Integration, or Why the EU Cannot Be a Social Market Economy. Socio-Economic Review 8(2): 211-250.

VAN MEURS, Wim-DE BRUIN, Robin-HOETINK, Carla-VAN LEEUWEN, KarinREIJNEN, Carlos-VAN DE GRIFT, Liesbeth. 2013. Europa in alle staten. Zestig jaar geschiedenis van de Europese integratie. Uitgeverij Vantilt, Nijmegen.

VAN MIDDELAAR, Luuk. 2013. The Passage to Europe: How a Continent Became a Union. Yale University Press, New Haven-London.

VAN PARIJS, Philippe. 2011. Linguistic Justice for Europe and for the World. Oxford University Press, Oxford.

WALLACE, Helen-POLLACK, Mark A.-YOUNG, Alasdair R. 2015. PolicyMaking in the European Union. Oxford University Press, Oxford.

WANG, Cong-STEINER, Bodo. 2015. Can Ethno-Linguistic Diversity Explain Cross-Country Differences in Social Capital? A Global Perspective. Economic Record 91(294): 338-366. 


\section{Files}

DE BRUIJN, Hans. 2012. Januskop van Rutte past ons allemaal. In: Trouw, 6 July. Dossier Wilders. 2010. Uitspraken van de meest besproken Nederlandse Politicus van deze eeuw. Onder redactie van Chris Willemsen. Uitgeverij House of Knowledge.

Eerste Kamer der Staten-General. 19 mei 2004, Afschaffing OALT gaat door. https://www.eerstekamer.ml/nieuws/20040519/afschaffing_oalt_gaat_door. Accessed on: 22 June 2015.

European Commission. June 2012. Special Eurobarometer 386. Europeans and Their Languages. European Court of Auditors, Secretariat General Translation Directorate.

September 2013. Misused English Words and Expressions in EU publications. Brussels - http://ec.europa.eu/translation/english/guidelines/documents/ misused_english_terminology_eu_publications_en.pdf. Accessed on: 18 February 2015.

JUNCKER, Jean-Claude. 27 December 2014. Nederlandse partijen te populistisch. NOS Teletekst. nos.nl/artikel/2010729-juncker-nederlandse-partijen-tepopulistisch.html.

22 November 2012 Rutte met 'pistool op zak' bij EU-onderhandelingen, RTL nieuws. http://www.rtlnieuws.nl/nieuws/rutte-met-pistool-op-zak-bij-euonderhandelingen. Accessed on: 25 February 2015.

14 October 2013 Rutte: participatie geen bezuiniging, NOS teletekst. nos.nl/ artikel/562390-rutte-participatie-geen-bezuiniging. Accessed on: 25 February 2015 . 